Article

\title{
Confirmation and Characterization of the First Case of Acetolactate Synthase (ALS)-Inhibitor-Resistant Wild Buckwheat (Polygonum convolvulus L.) in the United States
}

\author{
Balaji Aravindhan Pandian ${ }^{1}{ }^{\circledR}$, Abigail Friesen ${ }^{1}$, Martin Laforest ${ }^{2}{ }^{\circledR}$, Dallas E. Peterson ${ }^{1}$, \\ P. V. Vara Prasad ${ }^{1,3}$ and Mithila Jugulam ${ }^{1, * \mathbb{C}}$ \\ 1 Department of Agronomy, Kansas State University, Manhattan, KS 66506, USA; aravindhan@ksu.edu (B.A.P.); \\ abbylkroupa@gmail.com (A.F.); dpeterso@ksu.edu (D.E.P.); vara@ksu.edu (P.V.V.P.) \\ 2 Research and Development Centre, Agriculture and Agri-Food Canada (AAFC), Saint-Jean-sur-Richelieu, \\ QC J3B 3E6, Canada; martin.laforest@canada.ca \\ 3 Sustainable Intensification Innovation Lab, Kansas State University, Manhattan, KS 66506, USA \\ * Correspondence: mithila@ksu.edu; Tel.: +1-785-532-2755
}

Received: 10 September 2020; Accepted: 29 September 2020; Published: 1 October 2020

\begin{abstract}
Wild buckwheat (Polygonum convolvulus L.) is a problem weed and ALS-inhibitors (e.g., chlorsulfuron) are commonly used for its management. Recently, a population of wild buckwheat (KSW-R) uncontrolled with ALS-inhibitors was found in a wheat field in Kansas, USA. The objectives of this research were to determine the level and mechanism of resistance to chlorsulfuron and cross resistance to other ALS-inhibitors in the KSW-R population. In response to chlorsulfuron rates ranging from 0 to $16 \mathrm{x}(\mathrm{x}=18 \mathrm{~g}$ ai/ha), the KSW-R wild buckwheat was found $>100$-fold more resistant compared to a known ALS-inhibitor susceptible (KSW-S) wild buckwheat. Also, $>90 \%$ of KSW-R plants survived field recommended rates of sulfonylurea but not imidazolinone family of ALS-inhibitors. A portion of the ALS gene covering all previously reported mutations known to bestow resistance to ALS-inhibitors was sequenced from both KSW-R and KSW-S plants. The Pro-197-Ser substitution that confers resistance to the sulfonylurea herbicides was found in KSW-R plants. Our results support the evolution of high level of chlorsulfuron resistance as a result of a mutation in the ALS-gene in KSW-R buckwheat. This is the first case of resistance to any herbicides in wild buckwheat in the US.
\end{abstract}

Keywords: chlorsulfuron-resistant buckwheat; herbicide resistance; target-site mutation

\section{Introduction}

Wild buckwheat (Polygonum convolvulus L.) is a summer annual weed, commonly found in small grain crops such as wheat (Triticum aestivum) and oats (Avena sativa). This weed was introduced into the US from Europe via grain transport and became a problem weed throughout the Great Plains, Northern Plains, Canada's Prairie provinces, and US Midwest. Wild buckwheat is a competitive weed that can cause yield losses of up to $66 \%$ in wheat. Apart from competing for nutrients, the vines of wild buckwheat can tangle and climb on the shoots of host plants which interferes in harvesting operations leading to lower yields and poor quality [1,2]. Furthermore, chemical control of wild buckwheat is a challenge in small grain crops, because some auxinic herbicides (e.g., 2,4-dichlorophenoxyacetic acid (2,4-D) and 2-methyl-4-chlorophenomyacetic acid (MCPA)), widely used for control of broadleaf weeds in cereal crops are not effective in controlling wild buckwheat [3]. Hence, control of wild buckwheat in these crops is largely dependent on the use of acetolactate synthase (ALS)-inhibiting herbicides. 
ALS is one of the key enzymes involved in the biosynthesis of branched-chain amino acids (BCAAs) such as valine, leucine, and isoleucine [4]. Inhibition of the ALS enzyme leads to depletion of BCAAs and several secondary effects resulting in plant death [5]. ALS-inhibiting herbicides include five chemical families, viz., sulfonylurea (SU), imidazolinone (IMI), triazolopyrimidine (TP), pyrimidinyl-thio benzoates (PTB) and sulfonyl-aminocarbonyl-triazolinone (SCT). Since the commercialization of ALS-inhibitors in 1982, they are widely used for effective control of a broad spectrum of weeds compared to other commercial herbicides [6]. Because of extensive use, 165 weed species have evolved resistance to ALS-inhibitor herbicides [7].

Reduced sensitivity to ALS-inhibitors as a result of one or several mutations in the ALS gene, the target site of these herbicides is the most common resistance mechanism found in weeds [8]. A total of 29 amino acid substitutions at eight positions on the ALS protein (Ala-122, Pro-197, Ala-205, Asp-376, Arg-377, Trp-574, Ser-653, and Gly-654, positions based on the Arabidopsis thaliana sequence Genbank accession NP_190425) that confer resistance to ALS-inhibitors have been reported in many weed species [7]. Enhanced metabolism of ALS-inhibitors by cytochrome P450 monooxygenases (CYPs) activity has also been reported in several ALS-inhibitor-resistant weeds [6], such as waterhemp (Amaranthus tuberculatus) [9], Palmer amaranth (Amaranthus palmeri) [10], rigid ryegrass (Lolium rigidum) [11], late watergrass (Echinochloa oryzicola) [12], and blackgrass (Alopecurus myosuroides) [13].

Small grain crops such as wheat, oat, and barley (Hordeum vulgare) are naturally tolerant to the SU family of ALS-inhibitors [14]. Specifically, SU herbicides chlorsulfuron, triasulfuron, and thifensulfuron are widely used for postemergence control of wild buckwheat in these crops [2]. As a result of repeated selection, the evolution of resistance to ALS-inhibitors was reported in wild buckwheat biotypes in Canada and Australia [7]. ALS-inhibitor-resistant wild buckwheat was first reported in Queensland, Australia for chlorsulfuron in 1993 [7] and later in 2007 in Alberta (Canada), for SU and TP herbicide families [15]. An amino acid substitution, Trp-574-Leu in the ALS gene, was found to bestow resistance in the wild buckwheat population from Alberta [15]. Herbicide-resistant wild buckwheat has not been documented in the US; however, recently a population of wild buckwheat (KSW-R) survived chlorsulfuron applications in a wheat field in Marion County in Kansas. The focus of this research was to confirm and characterize the chlorsulfuron resistance in KSW-R wild buckwheat. This research was based on the hypothesis that similar to ALS-inhibitor-resistant wild buckwheat from Canada, one or more mutations in the ALS gene may contribute to chlorsulfuron resistance in KSW-R wild buckwheat. The objectives of this research were to determine the level and mechanism of resistance to chlorsulfuron and cross resistance to other ALS-inhibitors in KSW-R wild buckwheat.

\section{Materials and Methods}

\subsection{Plant Material and Growth Conditions}

A wild buckwheat biotype suspected to have evolved resistance to chlorsulfuron was collected from a winter wheat field in Marion County, Kansas in summer 2017. This population was designated as KSW-R and a biotype known to be susceptible to ALS-inhibitors, collected in Kansas (KSW-S) was also used in this study for comparison. The seeds of KSW-R and KSW-S wild buckwheat were planted in plastic trays $(25 \times 15 \times 2.5 \mathrm{~cm})$ with the commercial potting mixture (ProMix Ultimate, Premier Tech Horticulture, Mississauga, ON, Canada) and kept in $4{ }^{\circ} \mathrm{C}$ for $3-4$ weeks for a cold treatment to break the dormancy and enhance germination. Later, the trays were moved to a greenhouse. Upon germination, at the 2-3 leaf stage, seedlings were transplanted in square pots $(6 \times 6 \times 6 \mathrm{~cm})$ and grown in a greenhouse maintained at $25 / 20^{\circ} \mathrm{C}, 15 / 9 \mathrm{~h}$ a day/night photoperiod with a photosynthetic photon flux density of $750 \mu \mathrm{mol} \mathrm{m} \mathrm{m}^{-2} \mathrm{~s}^{-1}$ and relative humidity of $60 \pm 10$ percent. The plants were fertilized (Miracle GROßAll-purpose plant food, Scotts Miracle-Gro, Marysville, OH, USA) as needed. At the 4-5 leaf stage, KSW-R and KSW-S buckwheat plants were treated with chlorsulfuron (Glean ${ }^{\circledR}$ $\mathrm{XP}$, Wilmington, DE, USA) at $36 \mathrm{~g}$ ai ha ${ }^{-1}$ (field recommended rate $1 \mathrm{x}=18 \mathrm{~g}$ ai ha ${ }^{-1}$ ) along with $0.25 \%$ nonionic surfactant (NIS) using a bench-type sprayer (Research Track Sprayer, Generation 
III, De Vries Manufacturing, Hollandale, MN, USA) equipped with a flat-fan nozzle tip (80015LP TeeJet $\left(\right.$ tip, TeeJet Spraying Systems, Wheaton, IL, USA) delivering $168 \mathrm{~L} \mathrm{ha}^{-1}$ at $222 \mathrm{kPa}$ in a single pass at $4.8 \mathrm{~km} \mathrm{~h}^{-1}$. KSW-R plants that survived the treatment with $36 \mathrm{~g}$ ai ha ${ }^{-1}$ of chlorsulfuron were transferred to individual pots and allowed to self-pollinate. Upon maturity, seeds were collected from the self-pollinated plants and used in the dose-response and $A L S$ gene sequencing experiments.

\subsection{Chlorsulfuron Dose-Response Assay}

The KSW-R and KSW-S plants at the 3 to 4 leaf stage grown in square pots $(6 \times 6 \times 6 \mathrm{~cm})$ under greenhouse conditions as described above were used for the whole-plant dose-response assay. Six to ten plants of each KSW-S wild buckwheat treated with 0, 4.5, 9, 18 (field recommended rate), $36 \mathrm{~g} \mathrm{ai} \mathrm{ha}^{-1}$ and the KSW-R wild buckwheat were treated with $0,9,18,36,72,144$, and $288 \mathrm{~g}$ ai ha ${ }^{-1}$ of chlorsulfuron along with $0.25 \%$ NIS. The herbicide treatment was applied as described above. The above-ground dry biomass was collected at 3 weeks after treatment (WAT) and oven-dried at $60{ }^{\circ} \mathrm{C}$ for $72 \mathrm{~h}$, and then the dry weight of biomass was recorded. The dose-response experiment was repeated following the same experimental procedure, herbicide treatments, and growth conditions.

\subsection{Response to Different ALS-Inhibitors}

In order to determine the response of KSW-R and KSW-S biotypes to different ALS-inhibitors (SU or IMI), twelve plants of KSW-R and KSW-S wild buckwheat at the 4-5 leaf stage were treated separately with field recommended rates of thifensulfuron, halosulfuron, nicosulfuron, and imazethapyr along with chlorsulfuron (Table 1). Plant survival was assessed at 3 WAT as per [10]. The experiment was repeated following the same growth conditions and methods as above.

Table 1. List of herbicides used in the study.

\begin{tabular}{|c|c|c|c|c|}
\hline Herbicide & Trade Name & Chemical Family & Manufacturer & Field Rate \\
\hline Glean & Chlorsulfuron & Sulfonylurea & $\begin{array}{c}\text { DuPont } \\
\text { Wilmington, DE } \\
\text { http://cropprotection.dupont.com }\end{array}$ & $18 \mathrm{~g}$ ai ha $^{-1}$ \\
\hline Permit & Halosulfuron & Sulfonylurea & $\begin{array}{c}\text { Gowan Company, Yuma, AZ } \\
\text { www.gowanco.com }\end{array}$ & $36 \mathrm{~g}_{\text {ai ha }} \mathrm{h}^{-1}$ \\
\hline Harmony & Thifensulfuron & Sulfonylurea & $\begin{array}{c}\text { DuPont } \\
\text { Wilmington, DE } \\
\text { http://cropprotection.dupont.com }\end{array}$ & $36 \mathrm{~g}_{\text {ai ha }}{ }^{-1}$ \\
\hline Accent & Nicosulfuron & Sulfonylurea & $\begin{array}{c}\text { DuPont } \\
\text { Wilmington, DE } \\
\text { http://cropprotection.dupont.com }\end{array}$ & $36 \mathrm{~g}_{\text {ai ha }}{ }^{-1}$ \\
\hline Pursuit & Imazethapyr & Imidazolinone & $\begin{array}{c}\text { BASF Corporation, Research Triangle } \\
\text { Park, NC, USA }\end{array}$ & $72 \mathrm{~g}$ ai ha $^{-1}$ \\
\hline
\end{tabular}

\subsection{ALS Gene Sequencing}

To assess if any known mutations in the ALS gene of KSW-R wild buckwheat confer resistance to ALS-inhibitors, leaf tissue was collected from $15 \mathrm{KSW}-\mathrm{R}$ wild buckwheat plants that survived $288 \mathrm{~g}$ ai ha ${ }^{-1}$ of chlorsulfuron along with five non-treated individuals of KSW-S buckwheat. The genomic DNA (gDNA) was extracted using GeneJET TM Plant Genomic DNA Purification Mini Kit (Thermo Scientific ${ }^{\mathrm{TM}}$, Waltham, MA, USA) following the manufacturer's instructions. A wild buckwheat ALS gene sequence from a transcriptome assembly deposited at National Center for Biotechnology Information (NCBI) GenBank under the accession GIUI00000000 was used to design primers (PcALS_F: AGGGAGTCACCAACGTGTTC PcALS_R: TGGTAAAACCATACCCCCAGT; primer used for sequencing PcALS_F1: CATGCTGTTGAATAACCAGC) to amplify a portion of the ALS gene ( $\sim 1.8 \mathrm{~kb}$ in length) that covers all the previously reported mutation sites. Polymerase Chain reaction (PCR) was performed using T100 ${ }^{\mathrm{TM}}$ Thermal Cycler (Bio-Rad Inc., Hercules, CA, USA); a mixture containing 50-80 ng of gDNA, $0.5 \mu \mathrm{M}$ of forward primer, reverse primer and Promega ${ }^{\mathrm{TM}}$ ready-to-use 
PCR master mix with the following PCR conditions were used, initial denaturation $94{ }^{\circ} \mathrm{C}$ for $5 \mathrm{~min}$, followed by 35 cycles of denaturation at $94{ }^{\circ} \mathrm{C}$ for $30 \mathrm{~s}$, annealing at $55{ }^{\circ} \mathrm{C}$ for $30 \mathrm{~s}$ and extension at $72{ }^{\circ} \mathrm{C}$ for $45 \mathrm{~s}$ and a final extension at $72{ }^{\circ} \mathrm{C} 7 \mathrm{~min}$. The PCR products were purified using GeneJET TM PCR Purification Kit (Thermo Scientific ${ }^{\mathrm{TM}}$, Waltham, MA, USA) and sequenced by Sanger sequencing platform (GENEWIZ Inc., South Plainfield, NJ, USA), and the sequences were aligned using MultAlin multiple sequence alignment tool (INRA, Paris, France). Further, the Sanger sequencing reads were assembled using the one-click assembly option of EGassembler with default parameters [16]; the assembled sequence contig was translated using the Translate tool—ExPASy [17]. The assembled sequences of wild buckwheat populations KSW-R and KSW-S were deposited at the NCBI GenBank.

\subsection{Statistical Analysis}

The plant biomass accumulation (in grams per plant) data was converted to percent dry aboveground biomass relative to the non-treated control of the respective, wild buckwheat biotype, i.e., KSW-S and KSW-R. The relationship between herbicide rate and biomass accumulation was estimated by non-linear regression analysis using a three-parameter log-logistic model (1). All the analyses were performed [18] using the 'drc' [19] package in R [20]. To assess the fit of data to various regression models, a "Lack-of-fit" test was performed using the "model fit" function of 'drc':

$$
Y=\left\{\frac{d}{1}+\exp [b(\log x-\log e)]\right\}
$$

In the three-parameter log-logistic model Equation (1), $Y$ is the response variable, $d$ is the upper limit, $b$ is the slope of the curve, and e is the $\mathrm{GR}_{50}$ which is the rate required for $50 \%$ reduction of plant biomass [21]. Analysis of variance (ANOVA) was performed following Fisher's LSD test used to separate means at $p \leq 0.05$ using the 'agricolae' package in $\mathrm{R}$ [22] to estimate the significant differences in percent dry biomass in response to different rates of chlorsulfuron.

\section{Results and Discussion}

\subsection{Chlorsulfuron Dose-Response}

The results of the dose-response assay confirmed a very high level of resistance to chlorsulfuron in KSW-R wild buckwheat. No significant differences were found between two runs of dose-response $(p<0.05)$. The KSW-R plants survived up to $16 \mathrm{x}\left(288 \mathrm{~g}\right.$ ai ha- $\left.{ }^{-1}\right)$ of the field rate of chlorsulfuron. However, the KSW-S plants were heavily injured at 4.5 , and $9 \mathrm{~g}$ ai ha ${ }^{-1}$ and completely killed at $18 \mathrm{~g}$ ai ha ${ }^{-1}$ of chlorsulfuron (Figure 1). The percent reduction in the above-ground biomass relative to non-treated control did not show a significant difference up to $72 \mathrm{~g}$ ai ha ${ }^{-1}(p<0.05)$ rate of chlorsulfuron in the KSW-R; however, 16 and 25\% reduction in biomass was found in 144 and $288 \mathrm{~g}^{\text {ai ha }}{ }^{-1}$ treated plants, respectively (Figure 2). The GR Fo $_{5}$ of KSW-R (703.74) was exponentially higher than KSW-S (3.96), indicating that the KSW-R population is $>100$-fold resistant to chlorsulfuron than the KSW-S wild buckwheat (Table 2). The GR 50 of the KSW-R buckwheat was higher than the highest rate used (288 $\mathrm{g}$ ai $\mathrm{ha}^{-1}$ ) in this study; and the biomass reduction of KSW-R buckwheat was $<50 \%$ even at the highest rate (Figure 2). Previously, $\mathrm{GR}_{50}$ values that are more than the highest rate used in the experiments have been reported in several ALS-inhibitor-resistant weeds such as Palmer amaranth [10], henbit (Lamium amplexicaule) [23], and mouse barley (Hordeum murinum) [24]. Control of wild buckwheat in small grain crops, especially wheat, is primarily dependent upon ALS-inhibitors [2], and therefore, considerable selection pressure is expected in wheat producing regions. Resistance to ALS-inhibitor herbicides has been previously reported in a wild buckwheat population collected from wheat fields in Alberta (Canada) with 10-20-fold resistance to thifensulfuron/tribenuron and florasulam, respectively [15]. Similarly, a biotype of wild buckwheat from Queensland, Australia, also was found to have evolved resistance to chlorsulfuron [7], although the level of resistance or the mechanism of resistance to chlorsulfuron in the Australian biotype is not yet available. 

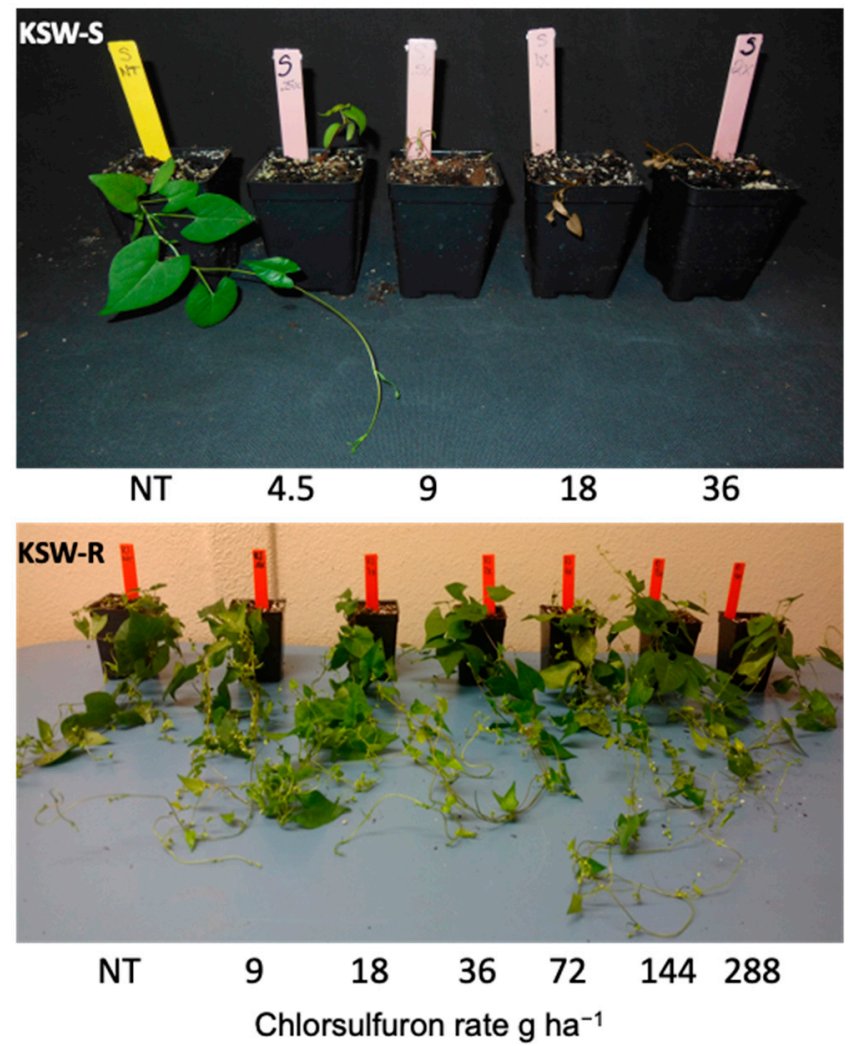

Figure 1. The whole-plant response of KSW-R (resistant) and KSW-S (susceptible) wild buckwheat populations to different rates of chlorsulfuron at 3 weeks after treatment.

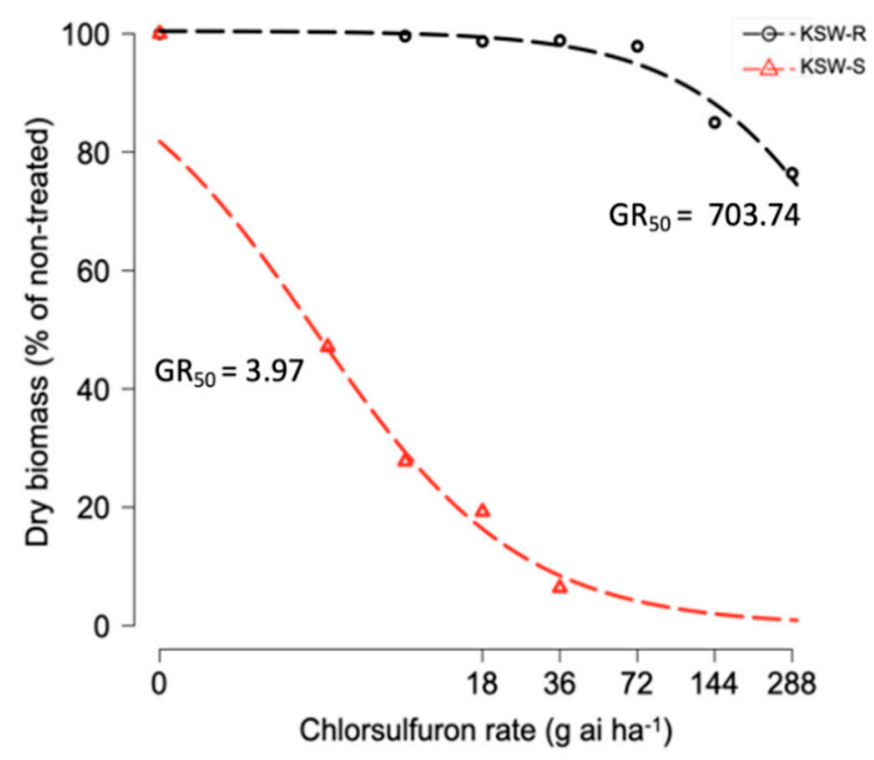

Figure 2. Chlorsulfuron dose-response curves obtained by three parameter log-logistic regression. $Y=\left\{\frac{d}{1}+\exp [b(\log x-\log e)]\right\}$ analysis of above-ground dry biomass of KSW-R (resistant) and KSW-S (susceptible) wild buckwheat at 3 weeks after treatment; $\mathrm{GR}_{50}$ herbicide rate required for $50 \%$ growth reduction. 
Table 2. Regression parameters describing the response of wild buckwheat populations KSW-R (resistant) and KSW-S (susceptible) to chlorsulfuron; herbicide rate required for $50 \%$ growth reduction $\left(\mathrm{GR}_{50}\right)$, slope of the curve (b), upper limit (d) and, standard error (SE).

\begin{tabular}{cccc}
\hline Genotype & GR $_{\mathbf{5 0}}$ (SE) & b (SE) & d (SE) \\
\hline KSW-R & $703.74(333.11)$ & $1.24(0.55)$ & $100.46(3.0)$ \\
KSW-S & $3.97(0.79)$ & $1.06(0.21)$ & $100.01(4.80)$ \\
\hline
\end{tabular}

\subsection{Response to Different ALS-Inhibitors}

In addition to chlorsulfuron, KSW-R buckwheat survived field recommended rates of other SU herbicides, e.g., thifensulfuron, halosulfuron, and nicosulfuron, but did not survive the application of imazethapyr (IMI herbicide). The KSW-S plant did not survive the applications of the above herbicides (Table 3). Cross-resistance to different ALS-inhibitors has been previously reported to be associated with altered ALS gene or due to CYP based metabolism of ALS-inhibitors in weed species [25,26]. Cross-resistance endowed by altered ALS gene depends on type of amino acid substitutions and weed species. The single nucleotide polymorphisms in the ALS gene resulting in common amino acid substitution at the Pro-197 position confers a high level of resistance primarily to SU herbicides in many weed species $[27,28]$. Nonetheless, other amino acid substitution at the same position, for example, Pro-197-Ser bestows cross-resistance to SCTs in addition to SUs [29], while Pro-197-Leu substitution provides high or moderate level of cross-resistance to herbicides in different families of ALS-inhibitors [27]. Amino acid substitutions at Ala- 122 or Ser-653 confer resistance to both IMI and SU herbicides, while Asp-376-Glu substitution provides resistance to all five chemical families and substitutions at Trp-574 confer resistance to IMIs, SUs, and TPs [27,30].

Table 3. Response of the KSW-R (resistant) and KSW-S (susceptible) wild buckwheat treated with different ALS inhibitors at their field rates at 3 weeks after treatment.

\begin{tabular}{cccc}
\hline \multirow{2}{*}{ Trade Name } & \multirow{2}{*}{ Field Rate } & \multicolumn{2}{c}{$\%$ Survival } \\
\cline { 3 - 4 } & & KSW-R & KSW-S \\
\hline Chlorsulfuron & $18 \mathrm{~g} \mathrm{ai} \mathrm{ha}^{-1}$ & $100 \%$ & $0 \%$ \\
Halosulfuron & $36 \mathrm{~g} \mathrm{ai} \mathrm{ha}^{-1}$ & $100 \%$ & $0 \%$ \\
Thifensulfuron & $36 \mathrm{~g} \mathrm{ai} \mathrm{ha}^{-1}$ & $90 \%$ & $0 \%$ \\
Nicosulfuron & $36 \mathrm{~g} \mathrm{ai} \mathrm{ha}^{-1}$ & $90 \%$ & $0 \%$ \\
Imazethapyr & $72 \mathrm{~g} \mathrm{ai} \mathrm{ha}^{-1}$ & $0 \%$ & $0 \%$ \\
\hline
\end{tabular}

${ }^{a} \mathrm{~A}$ total of 12 plants were treated and the number of plants that survived was expressed as the percent (\%) survival.

\subsection{Molecular Basis of ALS-Inhibitor Resistance in KSW-R Wild Buckwheat}

A high level of resistance to chlorsulfuron in KSW-R wild buckwheat (Table 2) indicates the possible presence of one or more previously reported mutations in the ALS gene. A portion of the ALS gene from $15 \mathrm{KSW}-\mathrm{R}$ and $5 \mathrm{KSW}-\mathrm{S}$ wild buckwheat individuals was sequenced. The amplified region includes all eight previously reported amino acid positions, i.e., Ala-122, Pro-197, Ala-205, Asp-376, Arg-377, Trp-574, Ser-653, and Gly-654 [27]. A single nucleotide polymorphism (C/T)CC resulting in amino acid substitution at position 197 from proline (CCC) to serine (TCC) was found in all the KSW-R but not in KSW-S wild buckwheat plants (Figure 3). These results suggest that alteration in the $A L S$ contributes to chlorsulfuron resistance in KSW-R wild buckwheat. Mutations in the ALS gene resulting in amino acid substitution is the most common mechanism of resistance to ALS-inhibitors in weed species [6]. All the $15 \mathrm{KSW}-\mathrm{R}$ buckwheat plants sequenced were homozygous for the Pro-197-Ser mutation. A high level of resistance to chlorsulfuron conferred by Pro-197-Ser substitution was previously reported in Palmer amaranth [10] and wild radish (Raphanus raphanistrum) [31]. However, in ALS-inhibitor-resistant wild buckwheat from Canada, an amino acid substitution, $\operatorname{Tr}_{574}$ Leu in the $A L S$ gene was found and this mutation also was shown to confer resistance to $S U$ and TP herbicides [15]. 
Although a wild buckwheat population resistant to chlorsulfuron was reported from Queensland (Australia), the mechanism of resistance has not been identified.

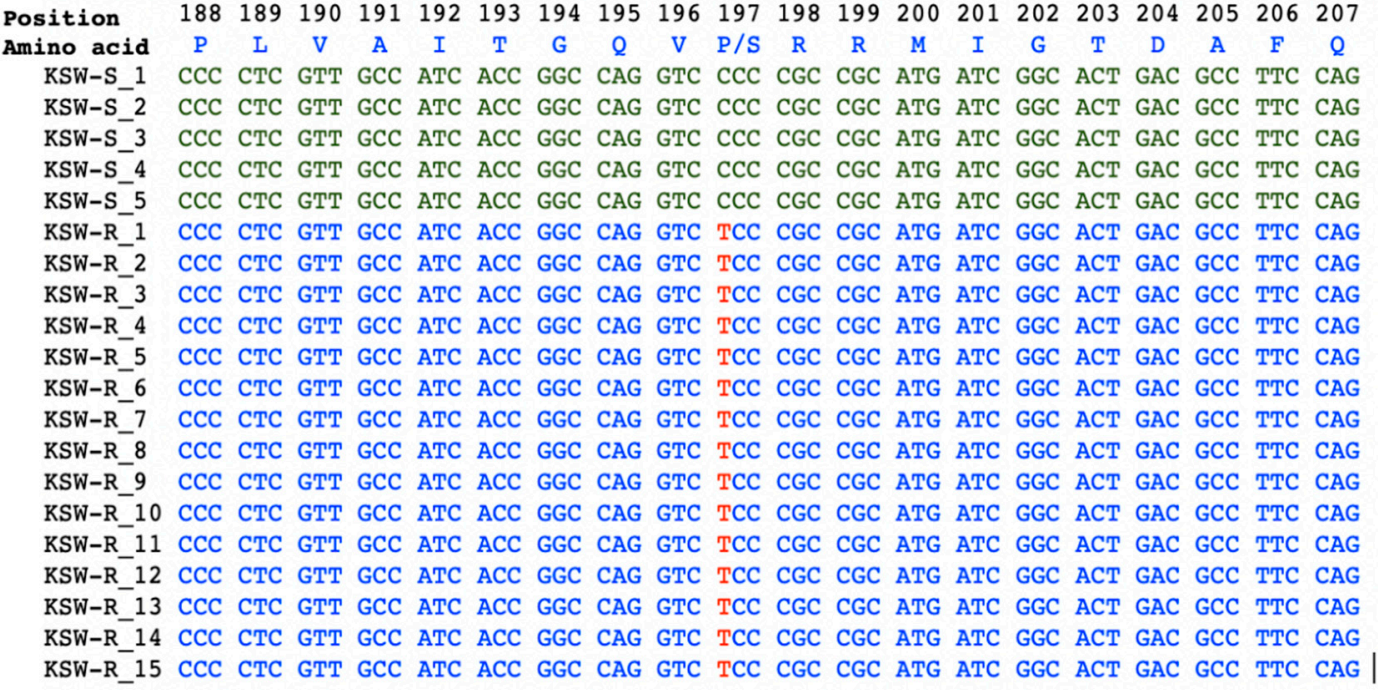

Figure 3. Nucleotide sequence alignment and analysis of a portion of the ALS gene sequence from KSW-R (15 resistant plants) and KSW-S (5 susceptible plants) wild buckwheat. Nucleotide/amino acid numbering refers to the Arabidopsis thatiana ALS gene sequence.

Since the Pro-197-Ser substitution is specific for resistance to SU and SCT herbicides in most weed species [27], the KSW-R wild buckwheat was found resistant to only SUs but not the IMI herbicides (Table 3). The evolution of target-site resistance leading to cross-resistance within the single group of herbicides essentially depends on the ALS protein structure and the amino acid domains on the protein. The ALS protein in higher plants generally will have five highly conserved domains, namely, A, B, C, $\mathrm{D}$, and $\mathrm{E}$ [31]. The domain A located in the N-terminal end consists of 13 amino acids including the Pro-197 [32]. Any mutations in domain A largely confer resistance to SU and/or TP, but moderate or no resistance to IMIs [27]. The SU herbicides interact with more amino acid residues compared to IMIs due to the difference in binding pockets making, SU resistance most common to several substitutions [29].

The coexistence of both target and non-target site resistance mechanisms such as altered ALS gene and enhanced metabolism of ALS-inhibitors in the same weed species has been reported [10,33,34]. Although altered ALS gene is known to confer a high level of resistance [28], enhanced metabolism also can bestow a high level of resistance in some weed species $[10,35,36]$. The presence of enhanced metabolism or other non-target site mechanisms such as reduced absorption or translocation also need to be tested in the KSW-R wild buckwheat to rule out contribution of non-target resistance mechanism to ALS-inhibitor resistance in this weed.

\section{Conclusions}

In conclusion, weed control in small grain crops such as wheat, oats, and barley are highly dependent on use of ALS-inhibitors. However, due to selection, several summer annual weeds, including wild buckwheat evolved resistance to these herbicides, which is a challenge for effective and efficient weed management. The evolution of resistance to SU herbicides in KSW-R is the first case of herbicide resistance in wild buckwheat in the US. Weed management strategies such as reducing the selection pressure by rotating herbicides with different modes of action, developing effective pre-emergence programs, use of weed-free crop seeds $s$ and other integrated management techniques along with improved stewardship need to be followed to reduce further spread and evolution of weed resistance. 
Author Contributions: M.J. conceived research hypothesis, methodology, led and supervised the research; B.A.P. and A.F. conducted the research and collected data; M.L. assisted with sequence analysis; D.E.P. identified and provided KSW-R and KSW-S wild buckwheat seed and P.V.V.P. co-supervised and partially supported funding of B.A.P. All authors have read and agreed to the published version of the manuscript.

Funding: This research received no external funding.

Acknowledgments: Graduate student assistantship to B.A.P. from Kansas Grain Sorghum Commission, Centre for Sorghum Improvement, and College of Agriculture is highly appreciated. WSSA-Undergraduate Research Award to A.F. to conduct this research is also much appreciated. This is contribution number 21-031-J from the Kansas Agricultural Experiment Station. The authors appreciate Sridevi Nakka and Amaranatha Reddy Vennapusa for their assistance in dose-response experiments and DNA extraction.

Conflicts of Interest: The authors declare no conflict of interest.

\section{References}

1. Forsberg, D.E.; Best, K.F. The emergence and plant development of wild buckwheat (Polygonum convolvulus). Can. J. Plant Sci. 1964, 44, 100-103. [CrossRef]

2. Zollinger, R.K.; Peterson, D.; Moechnig, M.J. Biology and Management of Wild Buckwheat; Purdue University Extension: West Lafayette, IN, USA, 2006; p. 11.

3. McCurdy, E.V.; Molberg, E.S. Effects of the continuous use of 2, 4-D and MCPA on spring wheat production and weed populations. Can. J. Plant Sci. 1974, 54, 241-245. [CrossRef]

4. Ray, T.B. Site of action of chlorsulfuron: Inhibition of valine and isoleucine biosynthesis in plants. Plant Physiol. 1984, 75, 827-831. [CrossRef] [PubMed]

5. Zhou, Q.; Liu, W.; Zhang, Y.; Liu, K.K. Action mechanisms of acetolactate synthase-inhibiting herbicides. Pestic. Biochem. Physiol. 2007, 89, 89-96. [CrossRef]

6. Tranel, P.J.; Wright, T.R. Resistance of weeds to ALS-inhibiting herbicides: What have we learned? Weed Sci. 2002, 50, 700-712. [CrossRef]

7. Heap, I. International Herbicide-Resistant Weed Database. Available online: www.weedscience.org (accessed on 25 August 2020).

8. Peterson, M.A.; Collavo, A.; Ovejero, R.; Shivrain, V.; Walsh, M.J. The challenge of herbicide resistance around the world: A current summary. Pest Manag. Sci. 2018, 74, 2246-2259. [CrossRef]

9. Guo, J.; Riggins, C.W.; Hausman, N.E.; Hager, A.G.; Riechers, D.E.; Davis, A.S.; Tranel, P.J. Nontarget-Site Resistance to ALS Inhibitors in Waterhemp (Amaranthus tuberculatus). Weed Sci. 2015, 63, 399-407. [CrossRef]

10. Nakka, S.; Thompson, C.R.; Peterson, D.E.; Jugulam, M. Target Site-Based and Non-Target Site Based Resistance to ALS Inhibitors in Palmer Amaranth (Amaranthus palmeri). Weed Sci. 2017, 65, 681-689. [CrossRef]

11. Busi, R.; Vila-Aiub, M.M.; Powles, S.B. Genetic control of a cytochrome P450 metabolism-based herbicide resistance mechanism in Lolium rigidum. Hered. 2010, 106, 817-824. [CrossRef]

12. Yun, M.-S.; Yogo, Y.; Miura, R.; Yamasue, Y.; Fischer, A.J. Cytochrome P-450 monooxygenase activity in herbicide-resistant and -susceptible late watergrass (Echinochloa phyllopogon). Pestic. Biochem. Physiol. 2005, 83, 107-114. [CrossRef]

13. Gardin, J.A.C.; Gouzy, J.; Carrère, S.; Délye, C. ALOMYbase, a resource to investigate non-target-site-based resistance to herbicides inhibiting acetolactate-synthase (ALS) in the major grass weed Alopecurus myosuroides (black-grass). BMC Genom. 2015, 16, 590. [CrossRef] [PubMed]

14. Nakka, S.; Jugulam, M.; Peterson, D.; Asif, M.; Mohammad, A. Herbicide resistance: Development of wheat production systems and current status of resistant weeds in wheat cropping systems. Crop. J. 2019, 7, 750-760. [CrossRef]

15. Beckie, H.J.; Warwick, S.I.; Sauder, C.A. Acetolactate Synthase (ALS) Inhibitor-Resistant Wild Buckwheat (Polygonum convolvulus) in Alberta. Weed Technol. 2012, 26, 156-160. [CrossRef]

16. Masoudi-Nejad, A.; Tonomura, K.; Kawashima, S.; Moriya, Y.; Suzuki, M.; Itoh, M.; Kanehisa, M.; Endo, T.; Goto, S. EGassembler: Online bioinformatics service for large-scale processing, clustering and assembling ESTs and genomic DNA fragments. Nucleic Acids Res. 2006, 34, W459-W462. [CrossRef]

17. Artimo, P.; Jonnalagedda, M.; Arnold, K.; Baratin, D.; Csardi, G.; De Castro, E.; Duvaud, S.; Flegel, V.; Fortier, A.; Gasteiger, E.; et al. ExPASy: SIB bioinformatics resource portal. Nucleic Acids Res. 2012, 40, W597-W603. [CrossRef] 
18. Shyam, C.; Jhala, A.J.; Kruger, G.; Jugulam, M. Rapid metabolism increases the level of 2,4-D resistance at high temperature in common waterhemp (Amaranthus tuberculatus). Sci. Rep. 2019, 9, 16695. [CrossRef]

19. Ritz, C.; Streibig, J.C. Bioassay analysis using R. J. Stat. Softw. 2005, 12, 1-22. [CrossRef]

20. R Core Team. R: A Language and Environment for Statistical Computing; R Foundation for Statistical Computing: Vienna, Austria, 2013; Available online: http://www.R-project.org/ (accessed on 15 June 2020).

21. Seefeldt, S.S.; Jensen, J.E.; Fuerst, E.P. Log-logistic analysis of herbicide dose-response relationships. Weed Technol. 1995, 9, 218-227. [CrossRef]

22. De Mendiburu, F. Agricolae: Statistical Procedures for Agricultural Research. CRAN Repository, 2014. Available online: https://cran.r-project.org/web/packages/agricolae/index.html (accessed on 15 June 2020).

23. Varanasi, V.K.; Godar, A.S.; Peterson, D.E.; Shoup, D.; Jugulam, M. A target-site point mutation in henbit (Lamium amplexicaule) confers high-level resistance to ALS-inhibitors. Weed Sci. 2016, 64, 231-239. [CrossRef]

24. Yu, Q.; Nelson, J.K.; Zheng, M.Q.; Jackson, M.; Powles, S.B. Molecular characterisation of resistance to ALS-inhibiting herbicides in Hordeum leporinum biotypes. Pest Manag. Sci. 2007, 63, 918-927. [CrossRef]

25. Beckie, H.J.; Tardif, F.J. Herbicide cross resistance in weeds. Crop. Prot. 2012, 35, 15-28. [CrossRef]

26. Iwakami, S.; Kamidate, Y.; Yamaguchi, T.; Ishizaka, M.; Endo, M.; Suda, H.; Nagai, K.; Sunohara, Y.; Toki, S.; Uchino, A.; et al. CYP 81A P450s are involved in concomitant cross-resistance to acetolactate synthase and acetyl-CoA carboxylase herbicides in Echinochloa phyllopogon. New Phytol. 2018, 221, 2112-2122. [CrossRef] [PubMed]

27. Tranel, P.J.; Wright, T.R.; Heap, I.M. Mutations in Herbicide-Resistant Weeds to ALS Inhibitors. Available online: http://www.weedscience.com (accessed on 25 August 2020).

28. A Gaines, T.; O Duke, S.; Morran, S.; Rigon, C.A.G.; Tranel, P.J.; Küpper, A.; E Dayan, F. Mechanisms of evolved herbicide resistance. J. Boil. Chem. 2020. [CrossRef]

29. Park, K.W.; A Mallory-Smith, C. Physiological and molecular basis for ALS inhibitor resistance in Bromus tectorum biotypes. Weed Res. 2004, 44, 71-77. [CrossRef]

30. Singh, S.; Singh, V.; Salas-Perez, R.A.; Bagavathiannan, M.; Lawton-Rauh, A.L.; Burgos, N.R. Target-site mutation accumulation among ALS inhibitor-resistant Palmer amaranth. Pest Manag. Sci. 2018, 8, 350. [CrossRef]

31. Yu, Q.; Zhang, X.Q.; Hashem, A.; Walsh, M.J.; Powles, S.B. ALS gene proline (197) mutations confer ALS herbicide resistance in eight separated wild radish (Raphanus raphanistrum) populations. Weed Sci. 2003, 51, 831-838. [CrossRef]

32. Eberlein, C.V.; Guttieri, M.J.; Berger, P.H.; Fellman, J.K.; Mallory-Smith, C.A.; Thill, D.C.; Baerg, R.J.; Belknap, W.R. Physiological consequences of mutation for ALS-inhibitor resistance. Weed Sci. 1999, 47, 383-392. [CrossRef]

33. Jugulam, M.; Shyam, C. Non-Target-Site Resistance to Herbicides: Recent Developments. Plants 2019, 8, 417. [CrossRef]

34. Rey-Caballero, J.; Menéndez, J.; Osuna, M.D.; Salas, M.; Torra, J. Target-site and non-target-site resistance mechanisms to ALS inhibiting herbicides in Papaver rhoeas. Pestic. Biochem. Physiol. 2017, 138, 57-65. [CrossRef]

35. Iwakami, S.; Endo, M.; Saika, H.; Okuno, J.; Nakamura, N.; Yokoyama, M.; Watanabe, H.; Toki, S.; Uchino, A.; Inamura, T. Cytochrome P450 CYP81A12 and CYP81A21 are associated with resistance to two acetolactate synthase inhibitors in Echinochloa phyllopogon. Plant Physiol. 2014, 165, 618-629. [CrossRef]

36. Shergill, L.S.; Bish, M.D.; Jugulam, M.; Bradley, K.W. Molecular and physiological characterization of six-way resistance in an Amaranthus tuberculatus var. rudis biotype from Missouri. Pest Manag. Sci. 2018, 74, 2688-2698. [CrossRef] [PubMed]

(C) 2020 by the authors. Licensee MDPI, Basel, Switzerland. This article is an open access article distributed under the terms and conditions of the Creative Commons Attribution (CC BY) license (http://creativecommons.org/licenses/by/4.0/). 